\title{
A therapod nesting trace with eggs from the upper cretaceous (Campanian) Two Medicine Formation of Montana
}

\author{
Authors: Frankie D. Jackson, Rebecca J. Schaff, David J. \\ Varricchio, \& James G. Schmitt
}

This is a postprint of an article that originally appeared in Palaios in May 2015.

Jackson, Frankie D., Rebecca J. Schaff, David J. Varricchio, and James G. Scmitt. "A therapod nesting trace with eggs from the upper cretaceous (Campanian) Two Medicine Formation of Montana." Palaios 38, no. 5 (May 2015): 362-372.

DOI: https://dx.doi.org/10.2110/palo.2014.052 


\title{
A therapod nesting trace with eggs from the upper cretaceous (Campanian) Two Medicine Formation of Montana
}

\author{
Frankie D. Jackson ${ }^{1}$, Rebecca J. Schaff ${ }^{2}$, David J. Varricchio ${ }^{1}$, and James G. Schmitt ${ }^{1}$ \\ ${ }^{1}$ Montana State University, Department of Earth Sciences, Bozeman, Montana 59717, USA \\ 26527 La Jolla St, Orlando, Florida 32818, USA
}

\begin{abstract}
A nesting trace preserved in alluvial floodplain deposits in the Upper Cretaceous Two Medicine Formation at the Willow Creek anticline in north-central Montana contains four crushed theropod eggs referable to the oospecies Continuoolithus canadensis. These eggs immediately overlie the lower surface of a 35-cm-long 3 7$\mathrm{cm}$-thick, dark-green mudstone lens, surrounded by reddish-purple mudstone. The long axes of three eggs are parallel to one another and to the lower boundary of the lens, whereas the fourth egg lies at a $30 \mathrm{u}$ angle to the others. A thin, 1-cm-thick organic horizon overlies the eggs, suggesting they were buried with some vegetation. Geometric modeling of the slightly asymmetrical C. canadensis eggs yields a volume and mass of approximately $194 \mathrm{~cm}^{3}$ and $205 \mathrm{~g}$ for each egg. This method provides a more accurate estimation for the surface area than allometric equations that are based on modern bird eggs because of the elongate shape of many non-avian theropod eggs. Pore density and water vapor conductance $\left(\mathrm{G}_{\mathrm{H} 2 \mathrm{O}}\right)$ calculated from one egg in the trace and five additional $\mathrm{C}$. canadensis eggs from the Willow Creek anticline vary across three regions. High, moderate, and very low $\mathrm{G}_{\mathrm{H} 2 \mathrm{O}}$ characterize the equatorial zone, blunt, and tapering poles, respectively. The average $\mathrm{G}_{\mathrm{H} 2 \mathrm{O}}$ for all eggs exceeds that of an avian egg of similar mass by 3.93 , thus supporting sedimentologic evidence of substrate burial during incubation.
\end{abstract}

\section{INTRODUCTION}

Among living amniotes, some turtles and geckos and all archosaurs (i.e., crocodilians and birds) produce hard-shelled eggs (Grigg and Beard 1985; Deeming 2006). The fertilized egg consists of the mineralized eggshell, organic shell membranes, albumen, yolk, and embryo (Seymour 1979; Board and Scott 1980; Grigg and Beard 1985; Booth and Seymour 1987). Pores traverse the eggshell and allow passive exchange of water vapor, oxygen, and carbon dioxide between the embryo and surrounding atmosphere (Board and Scott 1980). Studies of water vapor conductance rates $\left(\mathrm{G}_{\mathrm{H} 2 \mathrm{O}}\right)$ in extant bird and reptile eggs support a close relationship between eggshell porosity and microclimate of the nesting environment (Seymour 1979; Birchard and Kilgore 1980; Seymour and Ackerman 1980; Seymour et al. 1986; Booth and Seymour 1987, Seymour et al. 1987; Booth 1989).

The incubation strategy used by the adult helps regulate water vapor conductance between the egg and nest (Seymour and Ackerman 1980; Deeming 2002, 2004). For example, most birds' eggs are exposed to the atmosphere and attended by the adult, with the eggshell exhibiting low conductance rates that minimize water lost to evaporation. However, birds that incubate eggs in vegetation mounds or wet, humid conditions exhibit higher gas conductance rates (e.g., Alectura lathami (megapode) $=$ $1.7 \times$; Gavia immer $($ loon $)=4.2 \times$; Jackson et al. 2008 and references therein). Similarly, reptile eggs incubated in vegetation mounds or substrates under high humidity and $\mathrm{CO}_{2}$ and low $\mathrm{O}_{2}$ conditions typically exhibit 2-60 times higher water vapor conductance than avian eggs of comparable mass (Seymour and Ackerman 1980; Booth and Seymour 1987; Deeming 2002, 2004).

As in all living archosaurs, dinosaurs produced rigid-shelled eggs composed of calcite (Mikhailov et al. 1996). Presumably eggs of extinct taxa were subject to similar physiological and environmental constraints as modern eggs. The well-established relationship between $\mathrm{G}_{\mathrm{H} 2 \mathrm{O}}$ and incubation strategy in extant species has prompted analysis of fossil eggshell with the goal of understanding the incubation strategies of extinct animals (e.g., Seymour 1979; Williams et al. 1984; Deeming 2006; Grellet-Tinner et al. 2006, 2012; Jackson et al. 2008, Salvador and Fiorelli 2011; Fernández et al. 2013; Varricchio et al. 2013). However, results are often controversial, as discussed by several workers (e.g., Deeming 2006; Jackson et al. 2008; Varricchio et al. 2013). For example, rather than calculating the pore area from thin sections as in previous studies, Fernández et al. (2013) "predict" gas conductance based only on egg volume, an assumed density, and a porosity equivalent to that of a modern bird. This approach ignores the potential for substantial differences in eggshell porosity and thickness, both of which are vital for assessing $\mathrm{G}_{\mathrm{H} 2 \mathrm{O}}$. Further, the eggs were half buried in sediment, unlike those of any modern birds. Nevertheless, calculation of water vapor conductance rates can provide important evidence about the incubation environment. However, only a few studies (Jackson et al. 2008; Varricchio et al. 2013) combine taphonomic analysis of a nesting trace with calculation of $\mathrm{G}_{\mathrm{H} 2 \mathrm{O}}$ in order to interpret dinosaur nesting behavior. Further, only one theropod nesting trace (Troodon formosus) has been identified using sedimentologic characteristics (Varricchio et al. 1997, 1999). The paucity of such studies likely results from the preservation of many dinosaur nests in fine-grained, pedogenically modified mudstone. The homogeneous nature of these rocks contributes to the difficulty of recognizing trace fossil nests in the rock record (Chiappe et al. 2004).

Here, we report a nesting trace from the Flaming Cliffs locality (TM 160 ) in the Upper Cretaceous (Campanian) Two Medicine Formation at the Willow Creek anticline in Montana (Fig. 1). This trace fossil nest contains four crushed eggs that we assign to the oospecies Continuoolithus canadensis Zelenitsky et al. (1996). Diagnostic features permit assignment 
A

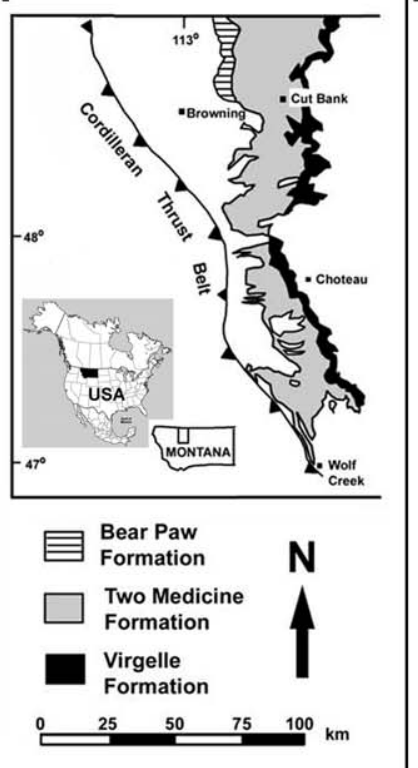

B

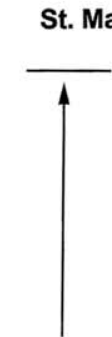

Two

Medicine

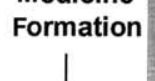

Hell Creek Formation

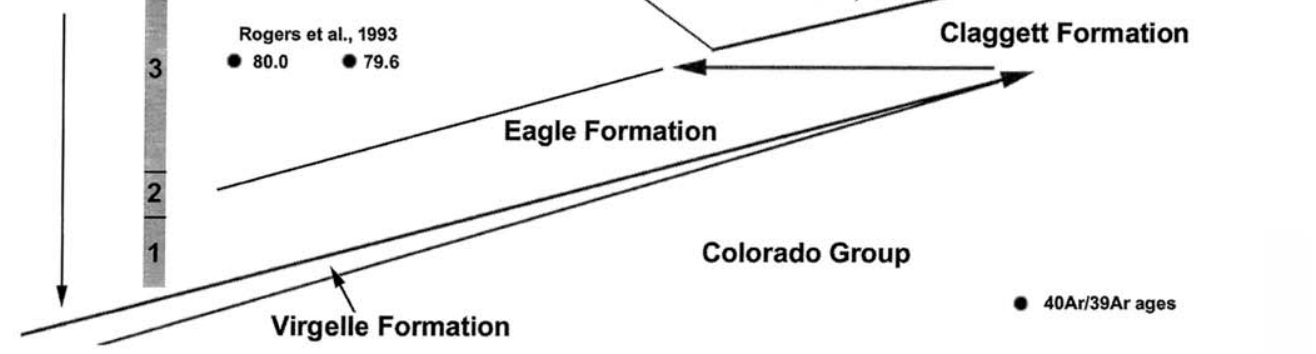

Fig. 1.-The Upper Cretaceous (Campanian) Two Medicine Formation and temporally and stratigraphically correlative units in Montana. A) Regional outcrop map of Upper Cretaceous exposures in northwestern and north-central Montana (modified from Rogers 1998). B) Stratigraphic diagram showing Two Medicine-Judith River clastic wedge with erosional unconformity across the Sweetgrass arch in west-central Montana and radiometric dates with citations. Modified from Eberth (1990).

of these eggs to a non-avian theropod: eggshell with two structural layers, elongate egg shape, squamatic structure in layer 2, and paired egg arrangement (Hirsch and Quinn 1990; Zelenitsky et al. 1996; Mikhailov 1997; Barta 2014). We describe the stratigraphic context and sedimentologic attributes of the trace and calculate $\mathrm{G}_{\mathrm{H} 2 \mathrm{O}}$ for an egg within this structure. We include five additional eggs from the Egg Mountain locality (TM 006), also at the Willow Creek anticline, in the analysis of $\mathrm{G}_{\mathrm{H} 2 \mathrm{O}}$ in order to investigate the range of variation among $C$. canadensis eggs. This study is important because it combines the physical evidence of behavior (trace fossil nest) with calculation of water vapor conductance in order to provide a better understanding of the incubation strategy of this Late Cretaceous theropod dinosaur.

\section{GEOLOGIC SETTING}

The Two Medicine Formation represents terrestrial coastal plain deposits of the western margin of the Late Cretaceous (Campanian) Western Interior Cretaceous Seaway (Fig. 1; Gill and Cobban 1973; Rogers 1998; Rogers et al. 1993). This 600-m-thick, nonmarine sequence consists of sediment derived from erosion of the Cordilleran fold and thrust belt and volcaniclastic materials from the Elkhorn Mountains volcanic center (Mudge 1970; Gill and Cobban 1973; Lorenz and Gavin 1984; Rogers et al. 1993; Lageson et al. 2001; Roberts and Hendrix 2000). Lithologies comprising the Two Medicine Formation include primarily lenticular meandering and anastomosed fluvial channel sandstone beds with associated floodplain mudstone successions (Lorenz and Gavin 1984; Lorenz 1981). Loading by emplacement of thrust allochthons in the fold and thrust belt contributed to flexural subsidence of the proximal foreland basin, allowing accumulation of the thick sedimentary deposits that characterize the study area (Rogers and Swisher 1996). The Two Medicine and Judith River clastic wedge (Fig. 1B) thins to the east (Mudge 1970; Rogers et al. 1993), intertonguing with transgressive marine shale of the Claggett and Bearpaw formations and marine nearshore deposits, including the Eagle Sandstone and Virgelle Formation in the region east of the Sweetgrass arch (Rogers et al. 1993; Rogers 1998).
Lorenz and Gavin (1984) described four lithofacies (A-D) of the Two Medicine Formation exposed near Choteau, Montana. Exposures at the Willow Creek anticline are made up of strata in their Lithofacies D and consist of four subfacies: (1) a lower subfacies of red to orange siltstone and mudstone with irregular calcareous nodules and interbedded gray lenticular sandstone deposited in an anastomosed fluvial system that grades upward into; (2) a middle lake subfacies of largely green to gray siltstone and micritic limestone that grades laterally northward into; (3) a middle northern subfacies deposited in a braided stream environment and typified by (a) trough cross-bedded channel sandstone, (b) primarily gray and green siltstone and shale, and (c) well-developed, thick limestone lenses; and overlain by (4) an upper subfacies of calcrete, siltstone, and thin channel sandstone lenses indicative of anastomosed stream deposition. Whereas most previously described eggs and clutches from the Willow Creek anticline come from the Egg Mountain locality (TM 006) of the middle lake subfacies, the Flaming Cliffs (TM 160) nesting site described in this study occurred within the middle northern subfacies of Lorenz and Gavin (1984). Geographically and stratigraphically, TM 006 and TM 160 are separated by $1.75 \mathrm{~km}$ and approximately $15 \mathrm{~m}$, respectively (Shelton 2007).

\section{MATERIALS AND METHODS}

\section{Sedimentologic and Stratigraphic Context}

The specimen (MOR 3062) consists of a 35-cm-long $\times$ 7-cm-thick, dark-green tapering mudstone lens containing four crushed theropod eggs. A 3.45 meter detailed stratigraphic section was measured through the excavation site in order to establish the stratigraphic framework for the lens and fossil material. Lithofacies were delineated following Miall's (1996) methods for alluvial deposits, and lithofacies distinctions made on differences in grain size, sorting, fabric, color, sedimentary structures, and ichnofossil content. In addition, individual lithologies were traced laterally over distances of tens of meters to document their overall geometry and any lateral lithofacies variation. A vertical microstratigraphic section was measured through the lens containing the fossil eggs. 
TABLE 1.- Variable and equations used in calculation of water vapor conductance.

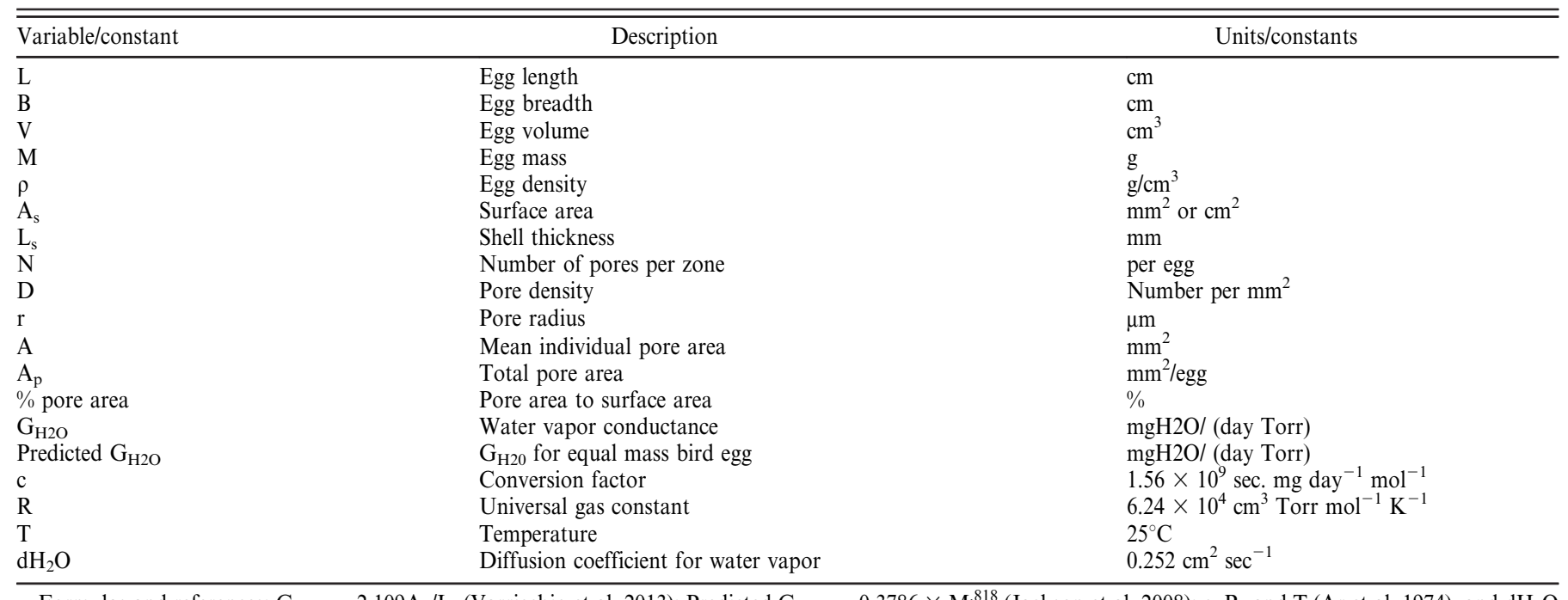

Formulas and references: $\mathrm{G}_{\mathrm{H} 2 \mathrm{O}}=2.109 \mathrm{~A}_{\mathrm{p}} / \mathrm{L}_{\mathrm{s}}$ (Varricchio et al. 2013); Predicted $\mathrm{G}_{\mathrm{H} 2 \mathrm{O}}=0.3786 \times \mathrm{M}^{.818}$ (Jackson et al. 2008); c, R, and T (Ar et al. 1974), and dH $\mathrm{H}_{2} \mathrm{O}$ (Varricchio et al. 2013).

\section{Rock Analyses}

Lithologic samples were removed from the lens containing the fossil material and underlying reddish-purple mudstone truncated by the lens for the following analyses:

Slabs.-Mudstone samples (S-F1, S-F2 and S-O, S-U3) were hand ground, using a $7 \mu \mathrm{m}$ grit and photographed with a Canon 5D Mark II digital SLR camera. Images were imported into ImageJ software for analysis.

Thin Sections.-Thin sections ( $30 \mu \mathrm{m}$ thick) were made of six samples removed from locations within and adjacent to the mudstone lens containing MOR 3062. These include S-F1, S-O, S-F2, and S-U3. Half of each slide was stained with Alizarin Red-S and potassium ferrocyanide in order to test for ferroan calcite and ferrous iron content, respectively. All slides were examined using a Nikon DS-L1-2M microscope with attached digital camera. Each thin section was photographed and images imported into ImageJ software.

Total Organic Carbon (TOC).--Three samples were tested for total organic carbon: S-F1, S-U3, and S-O. These samples were processed by National Petrographic Services Inc., Houston, Texas. A LECO CR-412 carbon analyzer was used to process dried and acidified sediments. Dried sediment was used to generate a percent mass for total carbon, whereas acidified sediment was used to determine the percent mass for organic carbon. All sediment was oxidized and carbon present converted to $\mathrm{CO}_{2}$. A nondispersive infrared (NDIR) detection cell allowed measurement of the mass of $\mathrm{CO}_{2}$ present, and this value was then converted to percent carbon based on dry sample weight. Total organic carbon content was subtracted from the total carbon content to calculate the total inorganic carbon content within the various samples.

\section{Egg and Eggshell Analyses}

The study focuses on the most complete egg (MOR 3062A) from the mudstone lens recovered from the Flaming Cliffs locality. The eggshell microstructure was compared to that of five additional eggs from the Egg Mountain locality: an isolated egg (YPM-PU 22544), three eggs from a partial clutch (MOR 326A, MOR 326B, MOR 326C), and an egg
(MOR 301B) found in close association with a relatively uncompressed and intact egg, MOR 301A. These eggs from the Egg Mountain locality were previously figured in Hirsch and Quinn (1990, fig. 9A-H).

For sampling, we considered the egg as consisting of three regions of equal length representing the tapering pole, equator, and the blunt pole. Although the blunt pole is incomplete, MOR 301B preserved a small portion, thus permitting sampling of this region. Two eggshell fragments were removed from each of the three regions on each of the six eggs. One fragment from each location was broken in half and prepared as radial and tangential thin sections. The second eggshell was mounted on a carboncovered aluminum stub, coated with iridium for 45 seconds, and imaged at 15 and $20 \mathrm{kV}$ with a JEOL 6100 scanning electron microscope (SEM). Eighteen radial and tangential thin sections (30 $\mu \mathrm{m}$ thick) were studied under a Nikon DS-L1-2M light microscope with an attached digital camera.

Water Vapor Conductance $\left(\mathbf{G}_{\mathbf{H} 2 \mathrm{O}}\right)$. - All six eggs (MOR 3062A, YPMPU 22544, MOR 326A, MOR 326B, MOR 326C, and MOR 301B) in this study exhibit lithostatic compaction. Because of this alteration in size and shape, egg dimensions (necessary for estimating $\mathrm{G}_{\mathrm{H} 2 \mathrm{O}}$ ) were obtained from a cast of MOR 301A (Hirsch and Quinn 1990, fig. 9B), an intact 12.34-cm-long egg associated with MOR 301B. The original egg from which the cast was made was unavailable at the time of this study. Empirical equations based on modern bird eggs allow estimation of egg volume (Hoyt 1979) and surface area (Paganelli et al. 1974) (Table 1). However, we modeled the dimensions of this elongate, slightly asymmetrical Mesozoic egg using a geometric method modified from Shott and Preston (1975) (see also Varricchio et al. 2013) and used a graphic projection of the egg to fit a partial sphere, two conical frusta, and a parabola. This allowed more precise calculations of total egg and regional volumes and surface areas than possible with the standard equations. These regions corresponded to the blunt pole, equatorial region, and tapering pole (Table 2). Similar studies of regional shell conductance in modern avian and crocodilian eggs typically use three zones (Booth and Seymour 1987; Rokitka and Rahn 1987; Balkan et al. 2006); therefore, we believe this number provides adequate sampling without undue destruction of fossil specimens.

One tangential eggshell thin section was made for each of three zones on the six eggs. Each eggshell fragment, as well as individual pores from within that fragment, was photographed. The total area of the eggshell 
TABLE 2.-Zonal dimensions of an ideal Continuoolithus egg.

\begin{tabular}{lcccccc}
\hline \hline Zone & Zone length $(\mathrm{cm})$ & Egg length $(\%)$ & Volume $\left(\mathrm{cm}^{3}\right)$ & Volume $(\%)$ & Surface area $\left(\mathrm{cm}^{2}\right)$ & Surface area $(\%)$ \\
\hline 1 & 4.11 & 33.3 & 41.3 & 21.3 & 48.80 & 27.1 \\
2 & 4.11 & 33.3 & 90.5 & 46.7 & 69.20 & 38.40 \\
3 & 4.11 & 33.3 & 61.7 & 31.9 & 180.40 & 34.6 \\
Totals & 12.33 & 100 & 193.5 & 100 & 100 \\
\hline
\end{tabular}

fragment, and the pore area and diameter, were determined using Image J (http://imagej.nih.gov/ij/) analysis software. To calculate percent pore area, the areas of all pores in each eggshell fragment were summed and compared to the total area of the eggshell fragment. This percentage was assumed to apply uniformly to the entire zone and used to calculate the total pore area $\left(A_{p}\right)$ for each zone. To calculate gas conductance, we assumed a temperature of $25^{\circ} \mathrm{C}$ and used the simplified equation $\mathrm{G}_{\mathrm{H} 2 \mathrm{O}}=$ $2.109 \times \mathrm{A}_{\mathrm{p}} / \mathrm{L}_{\mathrm{s}}\left(\mathrm{mg} \mathrm{H}_{2} \mathrm{O}\right.$ day $\left.^{-1} \mathrm{Torr}^{-1} \mathrm{~mm}^{-1}\right)$, with $\mathrm{A}_{\mathrm{p}}$ in $\mathrm{mm}^{2}$ and shell thickness $\left(\mathrm{L}_{\mathrm{s}}\right)$ in $\mathrm{mm}$ (see Varricchio et al. 2013 for details). This equation uses constants differing by less than 1\% from those used by Ar and Rahn (1985) and Deeming (2006), thus permitting direct comparison of results.

Water vapor conductance was determined from calculated data and measurements of egg attributes (pore area, shell thickness) using the equation and constants as described above and in Table 1. For determining the effective pore diameter and water vapor conductance, we assumed that the pore was circular in cross section, pore length between the nodes was equal to shell thickness, and pore diameter was consistent throughout its length. We used observed pore areas to calculate conductance values and per area conductance values for each zone, which aids in comparison of these zones. Total water vapor conductance for an egg equals the sum of the values calculated for each of the three zones. We also combined data from all six eggs to generate two sets of average egg values: first by simply averaging zonal values and second by averaging zonal values weighted by observed sample size.

Our method contrasts with most previous studies that assume a uniform pore density across the entire egg when calculating total pore area (e.g., Seymour 1979; Williams et al. 1984; Sabath 1991; Grigorescu et al. 1994; Deeming 2002, 2006; Jackson et al. 2008). Previous studies of gas conductance of dinosaur eggs often fail to describe sample size or the location of the eggshell on the egg. Further, these studies often analyze only 1-10 shell fragments (Kolesnikov and Sochava 1972; Seymour 1979; Williams et al. 1984; Sabath 1991; Grigorescu et al. 1994; Sahni et al. 1994; Deeming 2006; Jackson et al. 2008; Donaire and Lopéz-Martínez 2009). Grellet-Tinner et al. (2012) used a much larger sample, apparently calculating pores from the eggshell exterior, rather than from tangential thin sections. However, this may potentially increase pore area because of enlargement of the pore openings due to surface weathering. In addition, some pores exhibit funnel-shaped openings that exceed the pore diameter as measured midway through the shell. Thus, we advocate the use of thin sections for greater accuracy and to facilitate comparison among studies. With the exception of Varricchio et al. (2013), these earlier studies also assume uniform pore density over the surface of an idealized egg, rather than investigating regional gas conductance. We provide values for sample area, pore density, pore area, and $\mathrm{G}_{\mathrm{H} 20}$ from the three zones on all six eggs for comparison purposes and to examine the regional variation within Continuoolithus eggs. To make comparisons free of size scaling we employed a regression equation comparing avian egg mass and water vapor conductance in the manner of Seymour and Ackerman (1980), Ar and Rahn (1985), Deeming and Thompson (1991), and Deeming (2006). We use the equation of Jackson et al. (2008), $\mathrm{G}_{\mathrm{H} 2 \mathrm{O}}$ $=0.3786 \mathrm{M}^{0.818}$ because they were able to extend the regression of $\mathrm{Ar}$ and Rahn (1985) over a wider range of egg mass by calculating and incorporating the water vapor conductance for the extremely large egg of the elephant bird, Aepyornis. We assumed an average avian egg density of $1.06 \mathrm{~g} / \mathrm{cm}^{3}$ for the Continuoolithus eggs (Paganelli et al. 1974).

Repository.-With the exception of YPM-PU 22544 (Yale Peabody Museum, New Haven, Connecticut), all specimens are reposited at the Museum of the Rockies (MOR, Bozeman, Montana).

\section{RESULTS}

\section{Sedimentologic and Stratigraphic Context}

The $3.45 \mathrm{~m}$ interval containing the fossil material consists of more than $290 \mathrm{~cm}$ of light- to dark-gray, silty to sandy (very fine), blocky, massive mudstone (Fig. 2: Unit 1). Iron oxide (limonite) staining surrounds the edges of scattered small $(<1 \mathrm{~mm})$ plant fragments preserved in the rock matrix. This unit is overlain by a $40-\mathrm{cm}$-thick indurated reddish-purple, highly fractured silty to sandy calcareous mudstone (Unit 2). Numerous vertically to subvertically oriented light-green cylindrical, downwardbranching root traces ranging from $2-10 \mathrm{~mm}$ in width and $3-10 \mathrm{~cm}$ in length are also present throughout this calcareous mudstone unit. Thin $(<3 \mathrm{~cm})$ laterally discontinuous zones of light-green mudstone occur within the reddish-purple mudstone unit. In addition, a lenticular structure that consists of indurated, calcareous dark-green mudstone containing fossil eggs and eggshell debris (described below) was excavated from this unit. The reddish-purple mudstone is in turn overlain by an approximately $15-\mathrm{cm}$-thick interval of indurated, light-purple to lightgreen micrite (Unit 3).

\section{Lenticular Structure}

Field observations revealed a nonfissile, calcareous, dark-green lenticular structure that contained fossil eggs. In cross section, this lens measured $35 \mathrm{~cm}$ long and $7 \mathrm{~cm}$ high midway along its length and was tapered at both ends (Fig. 3A). Due to recent weathering the original width of the lens is unknown, and the number of preserved eggs may not necessarily represent the number laid by the female theropod. The composition and texture of the lens appeared comparable to the surrounding reddish-purple homogeneous mudstone (Fig. 2: Unit 2). However, the presence of fossil eggs and eggshells and differential weathering of the green mudstone lens facilitated its recognition in the field as a possible nesting trace. Although the specimen was prepared upside-down, as is typical of fossil eggs, the stratigraphy and fossil material are discussed and illustrated below in a stratigraphically upward direction.

The lower concave-up surface of the lens exhibits an abrupt and somewhat irregular contact with the underlying reddish-purple mudstone, and the partial eggs and eggshell debris immediately overlie this contact (Fig. 3A, B). Most of the egg portions consist of poorly preserved, closely superimposed eggshell fragments separated by light-green mudstone. This light-green mudstone was texturally indistinguishable from both the darkgreen mudstone of the lens and the reddish-purple mudstone that surrounded the lens. Although crushed by lithostatic compaction, four eggshell concentrations retain the approximate shape of the original eggs. These crushed eggs occur at similar depths, separated laterally from one another by about $1.0-2.5 \mathrm{~cm}$ (Fig. 3B, C). The long axes of three eggs are 

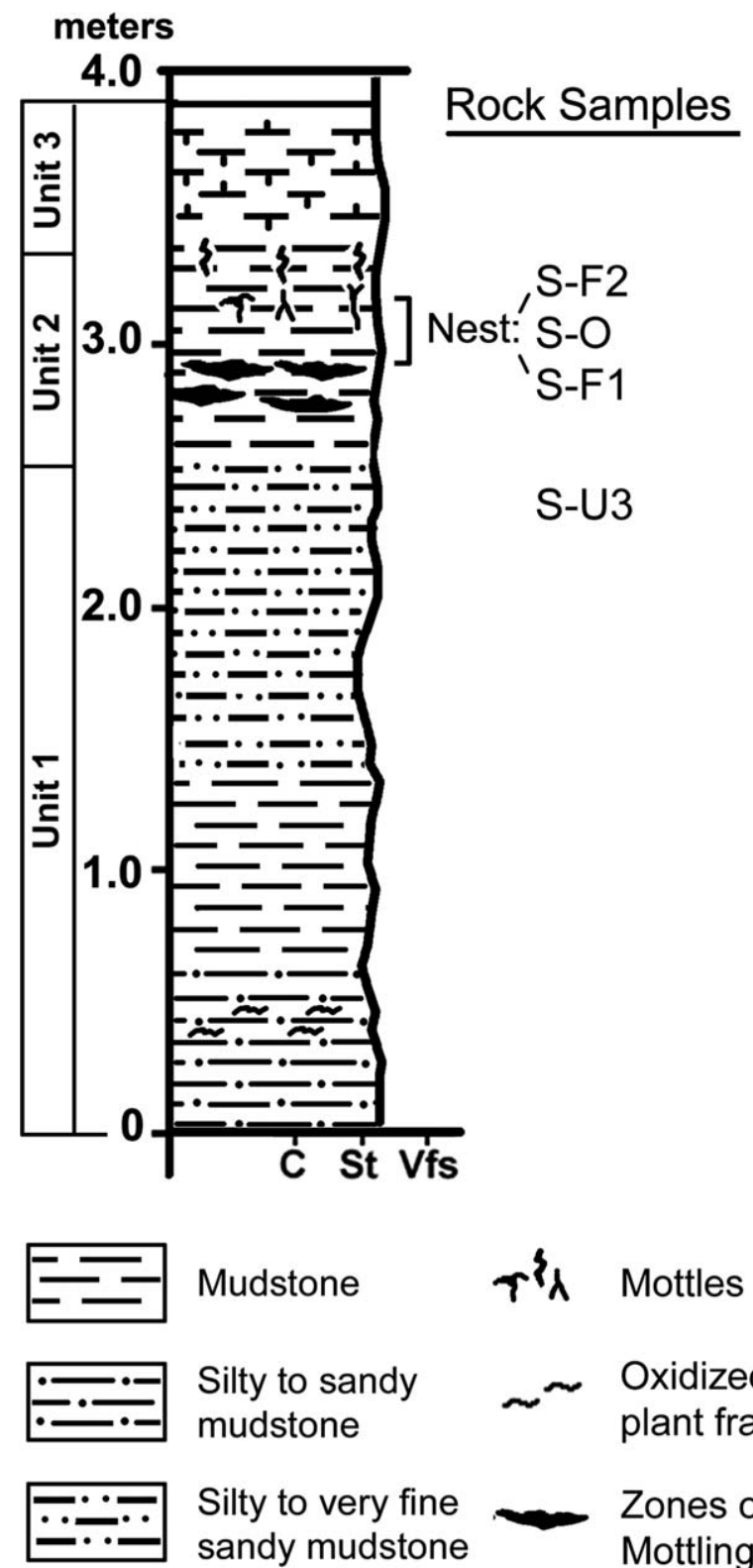

Mudstone

Silty to sandy
mudstone

\section{$r^{\hat{\lambda}}$ Mottles} Silty to very fine
sandy mudstone

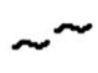

Oxidized plant fragments

Zones of Mottling

FIG. 2.- Stratigraphic section through Flaming Cliffs Quarry site.

parallel to one another and to the lower boundary of the lens; their exposed poles are truncated by recent weathering (Figs. 3C, D). A fourth crushed egg lies at a $30^{\circ}$ angle to the others and includes portions of the wide pole, equator, and tapering pole. This egg (MOR 3062A) measures about $9.86 \mathrm{~cm}$ long by $3.63 \mathrm{~cm}$ wide.

A 1- to 3-cm-thick interval of light-green silty mudstone overlies the horizon containing the crushed eggs, which in turn is overlain by a thin $(1 \mathrm{~cm})$ horizon of dark carbonaceous material, approximately midway through the lens (Fig. 3B, C, E; sample S-O). This organic horizon does not extend beyond the lens, and its greatest thickness occurs above the eggs and eggshell debris. The carbonaceous material includes amorphous organic matter and a minor amount of recognizable but taxonomically unidentifiable plant material. Green calcareous mudstone above the organic horizon gradually grades to a reddish-brown color. Only two eggshell fragments were present within this interval. Mottling increases in an upward direction and borders of these mottles become more distinct in the middle to upper portion of the lens (Fig. 3B). Green mudstone interdigitates with the overlying reddish-purple mudstone to produce an irregular upper boundary.

Total organic carbon (TOC) analyses show that mudstone samples associated with the zone of eggshell debris (S-F1) and within the carbonaceous horizon (S-O) contain $0.08 \%$ and $0.06 \%$ organic carbon, respectively (Fig. 3B, C; Schaff 2012). In contrast, the sample from the underlying reddish-purple mudstone truncated by the lens (S-U3) contains $0.01 \%$ organic carbon (Fig. 3B). Stained petrographic thin sections of the mudstone and organic horizon indicate significant amounts of iron in a reduced state.

\section{Eggshell Structure}

All eggshells examined from the Flaming Cliffs locality show similar morphology. The following description pertains to the best-preserved egg (MOR 3062A), which is used in the water vapor conductance analysis.

Including ornamentation, the eggshell samples from MOR 3062A vary in thickness from $0.82 \mathrm{~mm}$ at the tapering pole of the egg, $0.65 \mathrm{~mm}$ at the equator, and $1.0 \mathrm{~mm}$ at the blunt pole (Fig. 4A, B, Table 3). Without nodes these eggshells measure $0.81 \mathrm{~mm}, 0.65 \mathrm{~mm}$, and $0.79 \mathrm{~mm}$, respectively. Some of this variation may correspond to the location of the eggshell on the egg. However, the closely spaced, barrel-shaped mammillary cones at the inner eggshell surface of the tapering pole and equator show more extensive dissolution than eggshells from the larger, blunt pole. The more complete $1.0-\mathrm{mm}$-thick eggshell from the blunt pole consists of a $0.11-\mathrm{mm}$-thick inner mammillary layer (ML) and a 0.69 -mm-thick outer continuous layer (CL); including and excluding ornamentation the ML:CL ratio is about 1:6 and 1:7, respectively. A relatively distinct contact separates the mammillary and continuous layers. In thin sections, the continuous layer exhibits horizontal accretion lines that typically become more arched beneath the ornamentation at the outer eggshell surface (Fig. 4B). Scanning electron microscopy shows poorly preserved squamatic texture in the second structural layer, and in some samples prism boundaries are discernable in this layer (Fig. 4C). The narrow, straight pores that traverse the eggshell open adjacent to nodes on the eggshell surface and contain secondary calcite. The equator and blunt pole of the egg display nodes that occasionally coalesce to form ridges, whereas nodes are sparse or absent at the tapering pole. Tangential sections of eggshell show relatively abundant pores at the blunt pole that decrease toward the tapering end of the egg (Fig. 4D). Individual pore area varies in a similar manner (Table 3).

Comments.-The eggshell structure of MOR 3062A (Fig. 4A, B) closely resembles that of the five eggs from Egg Mountain (Hirsch and Quinn 1990, fig. 9A-H) used for comparison in this study. Although Hirsch and Quinn (1990) did not report prisms in the continuous layer, this feature occurs in MOR 3062A, MOR 326A, and MOR 326B (Fig. 4C). Similarly, Zelenitsky et al. (1996) did not mention this feature when establishing the new oospecies Continuoolithus canadensis, but the presence of prisms has since been confirmed in the Alberta specimens (D. Zelenitsky, personal communication, 2014). Further, Zelenitsky et al. (1996) did not include the Egg Mountain eggs in C. canadensis, noting that a greater CL:ML and somewhat thinner eggshell characterized the Alberta material. We attribute these differences in structural attributes to individual variation. Therefore, we refer the Willow Creek anticline eggs to $C$. canadensis because of the similarity of most features, which is further supported by the temporal and stratigraphic equivalence of the Two Medicine and Oldman formations.

Despite the presence of discernable prisms in the outer portion of Continuoolithus canadensis, the structure more closely resembles eggs of the Elongatoolithidae than Prismatoolithidae. Macroelongatoolithus from 

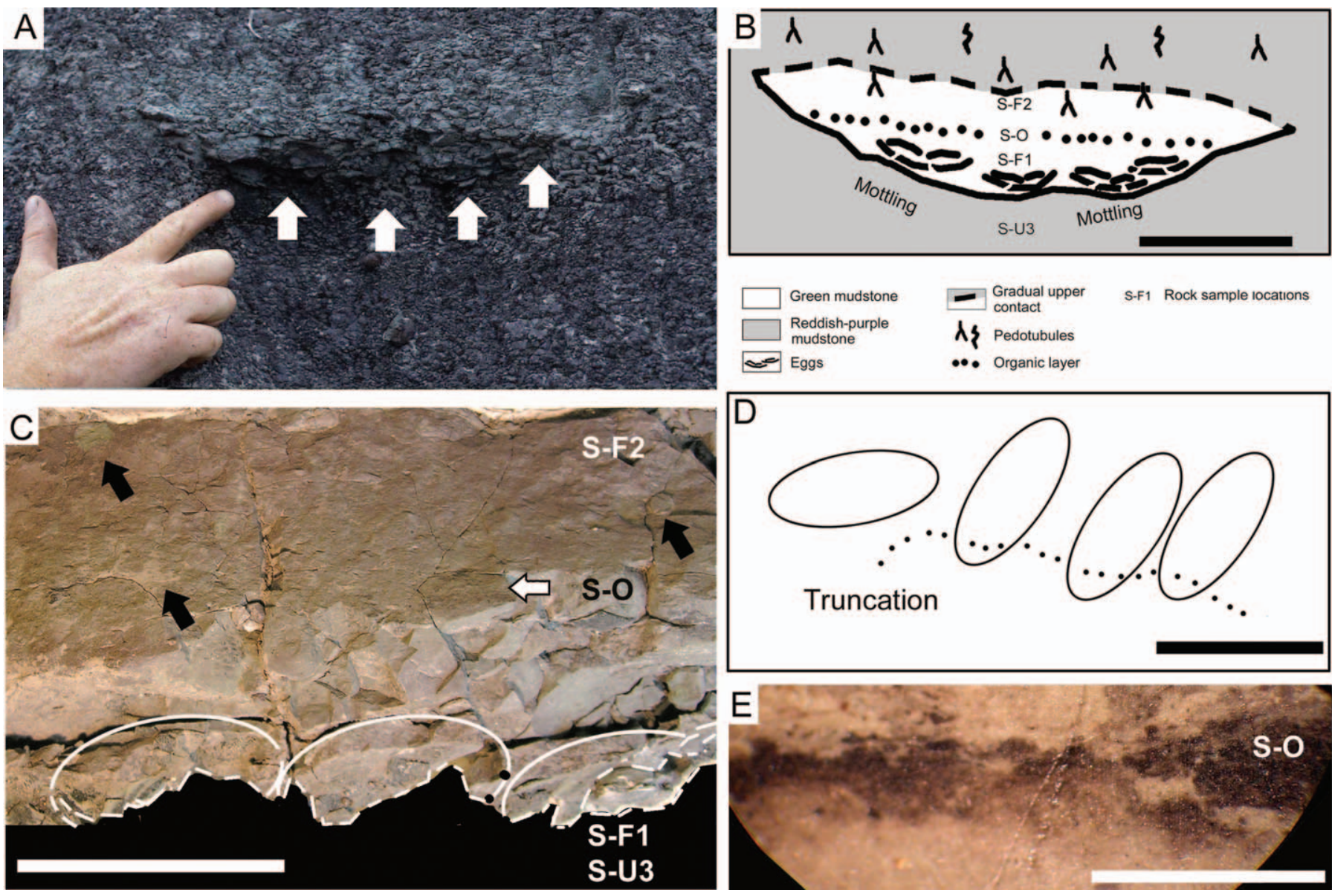

FIG. 3.-Nesting trace and eggs. A) Field photograph showing lens containing egg and eggshell debris. Hand for scale and arrows indicate weathered profile of eggs in cross section. B) Schematic diagram of lens and egg portions. Scale bar $=10 \mathrm{~cm}$. C) Partially prepped clutch showing four crushed eggs and microstratigraphy in original orientation. Two eggs overlap in lower right corner. Black arrows point to mottling and white arrow indicates the level of organic horizon. Letters and numbers show location of rock samples used in analyses. Sample S-U3 was removed from outside of interpreted nest trace, below S-F1. Scale bar $=10 \mathrm{~cm}$. D) Schematic diagram of eggs in plan view. Scale bar $=10 \mathrm{~cm}$. E) Enlargement of organic horizon shown in B and C; S-0 = rock sample location. Scale bar $=3 \mathrm{~cm}$.

China also exhibit prisms toward the outer surface of the egg (Jin et al. 2007); therefore, referral of $C$. canadensis to an oofamily remains problematic. Zelenitsky et al. (1996) chose not to assign the eggs to an oofamily and we concur with their approach at this time. Finally, the following synapomorphies permit assignment of $C$. canadensis to a theropod dinosaur: presence of structural layering of eggshell calcite, closely spaced mammillae relative to shell thickness, tabular structure, and squamatic texture that partly or completely obscures the prisms in layer 2 (Zelenitsky et al. 2002; Varricchio and Jackson 2004; GrelletTinner and Chiappe 2004; Jin et al. 2010; Barta 2014). Compared to Cretaceous avian eggs (e.g., Elzanowski 1981; Schweitzer et al. 2002; Kurochkin et al. 2013), their larger size and prominent ornamentation consisting of discrete and dispersed nodes suggests Continuoolithus are referable to a non-avian theropod.

\section{Eggshell Thickness, Pore Area, and Pore Density}

To increase the sample size for calculating water vapor conductance $\left(\mathrm{G}_{\mathrm{H} 2 \mathrm{O}}\right)$, we combined data from MOR 3062A from the Flaming Cliffs with five additional Continuoolithus canadensis eggs from Egg Mountain (Table 3). Eggshell thicknesses for the six eggs varied depending on quality of preservation and sampling location. Mean eggshell thickness and standard deviation (SD) for all eggs were $1.0(0.16) \mathrm{mm}$ and 0.87 (0.11) $\mathrm{mm}$, including and excluding ornamentation, respectively. Mean regional values were $0.93(0.94) \mathrm{mm}$ at the blunt pole, $0.86(0.11) \mathrm{mm}$ at the equator, and $0.83(0.12) \mathrm{mm}$ at the tapering pole (Schaff 2012).

The total sampled area for the six eggs used to assess pore area and density typically varied from about $9-34 \mathrm{~mm}^{2}$; however, four samples consisted of extremely small eggshell fragments with areas from $2-6 \mathrm{~mm}^{2}$ (Table 3). Pore radius ranged from $25-83 \mu \mathrm{m}$, with an average of $47 \mu \mathrm{m}$, yielding an average area of $0.007(0.0024) \mathrm{mm}^{2}$. Regional mean individual pore area was $0.0082(0.0016) \mathrm{mm}^{2}$ for the blunt pole, $0.0071(0.003) \mathrm{mm}^{2}$ for the equator, and $0.0057(0.0021) \mathrm{mm}^{2}$ for the tapering pole. Pore densities varied from $0.1-1.59$ pores per $\mathrm{mm}^{2}$, whereas mean pore densities were $0.4,0.7$, and 0.3 pores per $\mathrm{mm}^{2}$ at the blunt pole, equator, and tapering pole, respectively (Table 3 ).

\section{Water Vapor Conductance}

The egg cast used in this study (MOR 301A) measured $12.34 \mathrm{~cm}$ long, with a diameter of $5.56 \mathrm{~cm}$ (Table 4). Equations developed from modern eggs (Paganelli et al. 1974; Hoyt 1979) estimated a volume and surface area of $194.6 \mathrm{~cm}^{3}$ and $165.7 \mathrm{~cm}^{2}$, respectively (Table 4). The geometric model produced a volume estimate of $193.5 \mathrm{~cm}^{3}$, differing from that obtained by equations by less than $0.6 \%$. In contrast, the geometric model estimated surface area as nearly $9 \%$ larger, namely $180.4 \mathrm{~cm}^{2}$, and this likely reflects the very narrow and elongate dimensions of this egg. Although the geometric values were used for conductance calculations, 

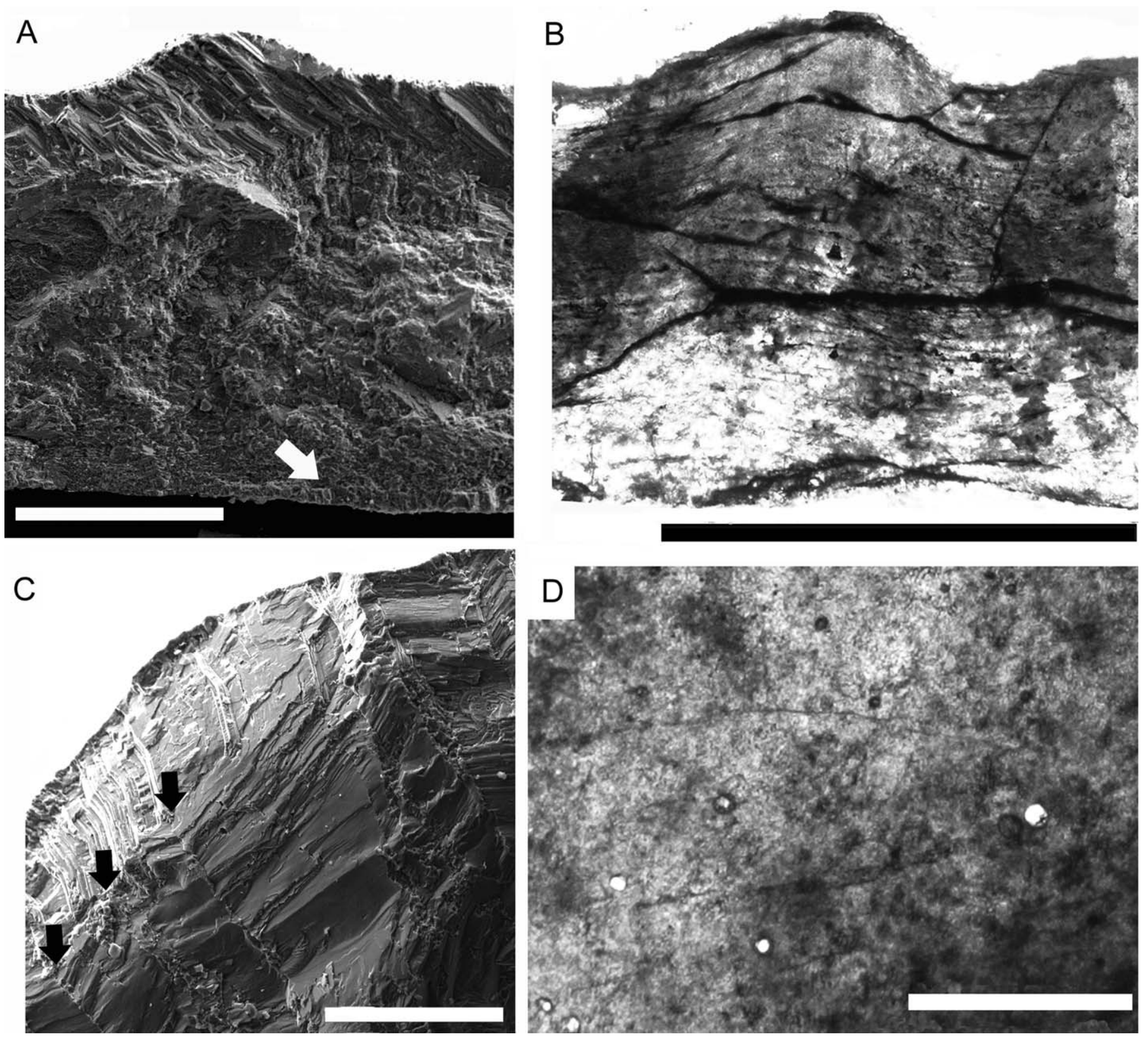

FIG. 4.-MOR 3062A eggshell structure. A) SEM image of eggshell. Outer surface of the eggshell is at the top of the image. Arrow marks upper boundary of the incomplete mammillary layer. Scale bar $=0.5 \mathrm{~mm}$. B) Thin section in plane-polarized light. Scale bar $=1 \mathrm{~mm}$. C) Prismatic structure toward the outer eggshell surface Arrows indicate prism margins. Scale bar $=0.5 \mathrm{~mm}$. D) Tangential thin section of eggshell showing several calcite-filled pores. Scale bar $=1 \mathrm{~mm}$.

we note that some flattened Continuoolithus eggs (e.g., YPU-PU 22544) appear to have a broader profile. This may be the result of their greater degree of lithostatic compaction or reflect variation in the overall Continuoolithus form. Consequently, values produced by either the geometric or avian model should be considered estimates. Assuming an average avian egg density of $1.06 \mathrm{~g} / \mathrm{cm}^{3}$ (Paganelli et al. 1974) yielded an egg mass of $205 \mathrm{~g}$ (Table 4).

Zonal conductance values varied widely among the five eggs, from a low of $6.39 \mathrm{mg} \mathrm{H} 2 \mathrm{O} /$ (day Torr) at the tapering pole of MOR 3062A to a high of $158 \mathrm{mg} \mathrm{H} 2 \mathrm{O} /$ (day Torr) at the equatorial zone of MOR 326C (Table 3). Variation occurred even within a given zone with the tapering, equatorial, and blunt regions ranging from 6.39 to $46.7,34.8$ to 158 , and 23.1 to $101 \mathrm{mg} \mathrm{H} 2 \mathrm{O} /($ day Torr), respectively. Some of this variation certainly represents sample size; for example, the extremely high value of the MOR 326C equator is associated with the smallest sample area (Table 3).

Ignoring sample size, the water vapor conductance rates for the six eggs ranged from 82 to $210 \mathrm{mg} \mathrm{H} 2 \mathrm{O} /($ day Torr), with a total mean for all the eggs of $143 \mathrm{mg} \mathrm{H} 2 \mathrm{O} /$ (day Torr) (Table 3). If one weights the conductance values by sample size, then the total mean water vapor conductance rate for the six eggs was $116 \mathrm{mg} \mathrm{H} 2 \mathrm{O} /($ day Torr). Additionally, there are major differences in the conductance between the three equal-area zones. When weighted by sample size, the equatorial region had the highest mean porosity and contributed $46 \%$ of the conductance, whereas the blunt pole was nearly as porous, with $37 \%$ of the conductance. However, the tapering pole was far less porous, with values less than half that of the 
TABLE 3.- Measurements of pores, sampled area, and gas conductance for MOR $3062 \mathrm{~A}$ and five eggs from the Egg Mountain locality.

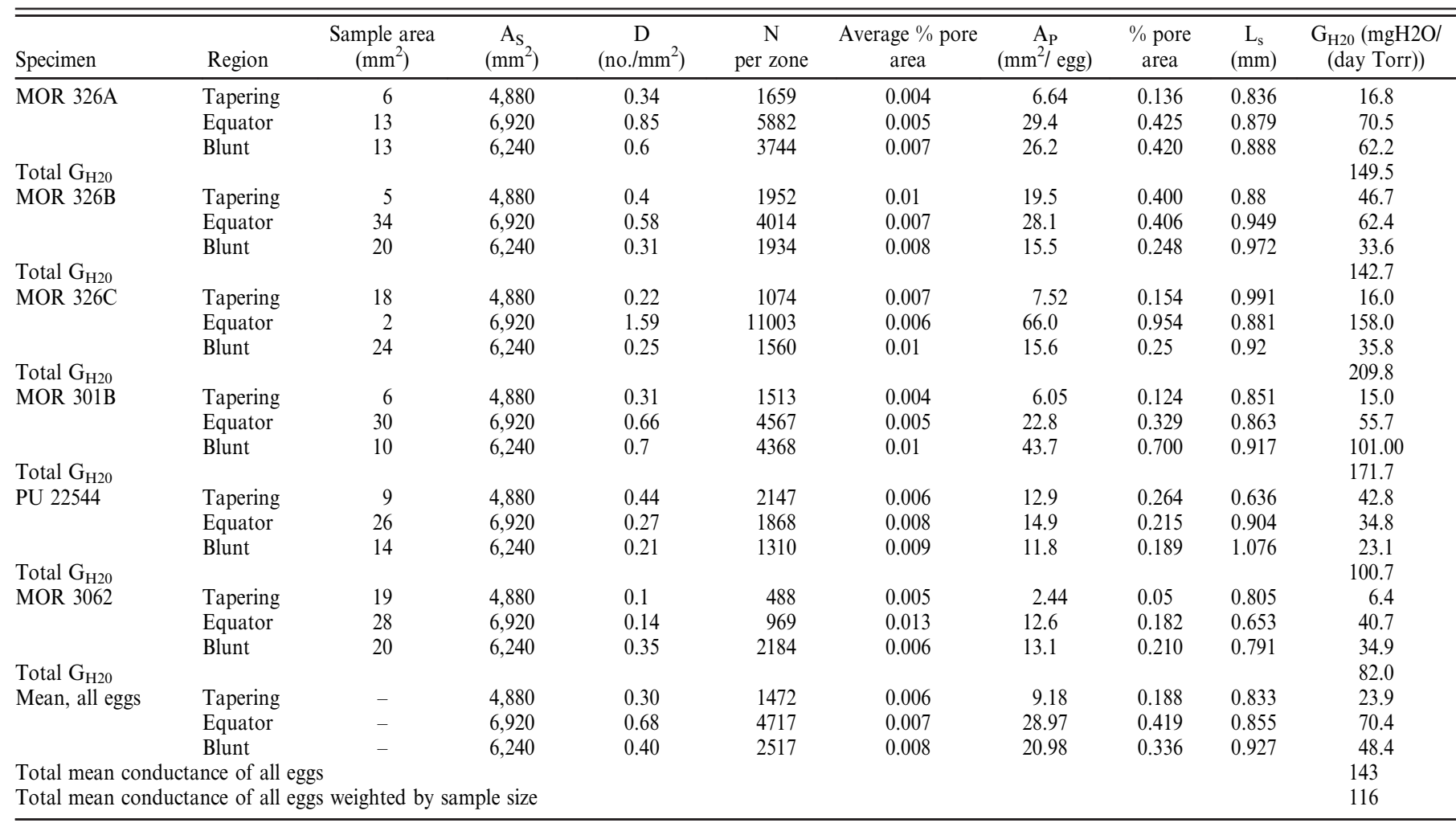

equatorial zone, contributing only $17 \%$ to the entire egg conductance. Unweighted percentages of total $\mathrm{G}_{\mathrm{H} 2 \mathrm{O}}$ are similar, with 49.3, 33.9, and 17 for the equator, blunt pole, and tapering pole, respectively. The water vapor conductance of an avian egg of equivalent mass, as predicted by the equation of Jackson et al. (2008), is $29.5 \mathrm{mg} \mathrm{H} 2 \mathrm{O} /($ day Torr). Thus, the Continuoolithus egg had a conductance value 3.9 times greater than that expected for an avian egg of comparable mass.

\section{DISCUSSION}

The stratigraphic sequence at the Flaming Cliffs documents deposition on an alluvial floodplain, with vertical accretion of sediment through suspension settling of silt and clay during periods of flooding (Fig. 2; Moody et al. 1999). The reddish-purple color of the mudstone containing the lenticular structure (Figs. 2, 3A) and fossil material reflects the presence of iron oxides (e.g., hematite), indicating a well-drained, oxidized soil (Retallack 1990). Subsequent modification of these deposits occurred as a result of bioturbation and establishment of vegetation that accompanied pedogenesis. The light-purple to light-green micrite directly

TABLE 4.-Measurements for a Continuoolithus egg, with comparison to those derived from geometric methods used in the study.

\begin{tabular}{lllcc}
\hline \hline Variable & Description & Units & Data & $\begin{array}{c}\text { Geometric } \\
\text { method }\end{array}$ \\
\hline $\mathrm{L}$ & Egg length & $\mathrm{cm}$ & 12.34 & - \\
$\mathrm{B}$ & Egg breadth & $\mathrm{cm}$ & 5.56 & - \\
$\mathrm{V}$ & Egg volume & $\mathrm{cm}^{3}$ & 194.6 & 193.5 \\
$\mathrm{~A}_{\mathrm{s}}$ & Surface area & $\mathrm{cm}^{2}$ & 165.7 & 180.4 \\
$\mathrm{M}$ & Egg mass & $\mathrm{g}$ & 205.1 & - \\
$\rho$ & Egg density & $\mathrm{g} / \mathrm{cm}^{3}$ & 1.06 & - \\
\hline
\end{tabular}

above the fossil-bearing reddish-purple mudstone interval likely represents deposition in a carbonate-producing, ponded water setting (palustrine or lacustrine) (e.g., Freytet and Verrecchia 2002). Alternatively, it may record the onset of conditions supporting development of calcrete, which may form as pedogenic (soil) or phreatic (groundwater) carbonate (Wright and Tucker 1991). Pedogenic calcrete development requires only a net seasonal moisture deficit, rather than an arid climate (Goudie 1983). Therefore, conditions favoring palustrine/lacustrine carbonate mud (micrite) precipitation at the surface do not preclude those favoring subsequent calcrete (pedogenic or phreatic) development. Indeed, Wright and Tucker (1991) suggest that palustrine carbonate deposits may be subsequently modified by pedogenic and/or phreatic calcrete forming processes.

\section{The Nest Structure}

The dark-green color of the egg-bearing lenticular structure reflects reducing conditions, as evidenced by the lack of oxidized iron in unstained thin sections. Both the lens and surrounding reddish-purple mudstone preserve organic matter. However, samples from the green mudstone lens show $0.06 \%$ and $0.08 \%$ total organic carbon, compared to $0.01 \%$ TOC for the surrounding reddish-purple mudstone (Unit 2). Preservation of plant matter within the lenticular structure, including the thin carbonaceous horizon overlying the eggs, likely resulted from lower oxygen content compared to the surrounding sediment, perhaps augmented by higher moisture content derived from decomposition of a greater abundance of plant debris as well as the egg contents. Poor soil aeration and absence of gaseous oxygen facilitates increased activity by anaerobic organisms, whereas the activity of aerobic organisms declines under these conditions (Retallack 1990; Brady and Weil 2002). This suppression of aerobic organisms results in much slower breakdown of organic matter, as seen in modern-day Histosols (Brady and Weil 2002). 
Preservation of vertebrate remains (including eggshell) typically requires a different oxidation-reduction (redox) potential than plants. Low to negative Eh facilitates plant preservation, whereas high $\mathrm{pH}$ conditions preserve invertebrate shell, eggshell, and vertebrate remains (Retallack 1997). The combination of eggshell and plant matter suggests relatively high $\mathrm{pH}$ and low to negative Eh within the mudstone lens after deposition (sensu Retallack 1997). Alternatively, these conditions may have developed after transition of the soil complex to the freshwater phreatic zone during burial.

Chiappe et al. (2004) suggest that pedogenic and diagenetic processes may alter color and that this attribute alone provides unreliable evidence for inferring nest structure, even in the presence of eggs and juvenile remains. Compared to nesting traces preserved in sandstone, as described by Chiappe et al. (2004), mudstone presents a greater challenge for meeting their criteria for recognition of nest traces. Nevertheless, we interpret the green lenticular mudstone containing the fossil material as a nesting trace for several reasons. First, the lower concave surface of the lens abruptly truncates the underlying reddish-purple mudstone and the four crushed eggs rest on this truncated surface. Second, a greater abundance of plant fragments and higher percentage of TOC also characterize the nesting trace, compared to the surrounding reddish-purple mudstone. Finally, the carbonaceous horizon that overlies the eggs is confined to the lens and does not extend into the surrounding mudstone.

The partial Continuoolithus canadensis eggs preserved within the nesting trace differ in some ways from eggs previously described from Egg Mountain (Horner 1987, 1997; Hirsch and Quinn 1990). Although the length $(123 \mathrm{~mm})$ of the best-preserved specimen approximates that reported by Hirsch and Quinn (1990), its greater width $(36 \mathrm{~mm})$ differs substantially. However, all Continuoolithus eggs from Egg Mountain are preserved in micrite (Hirsch and Quinn 1990); therefore, greater lithostatic compaction of fine-grained fluvial deposits at the Flaming Cliffs locality may explain this difference. Hirsch and Quinn (1990) also describe egg pairing in two "linear" clutches from Egg Mountain, one containing six eggs and the other three. The Flaming Cliffs specimen includes three eggs with their long axes parallel to each other and to the lower surface of the nesting trace, whereas the fourth egg lies perpendicular to these specimens in the horizontal plane (Fig. 3B-D). This difference in orientation may result from incomplete clutch preservation, disruption during nesting, or other unknown factors.

We suggest the following sequence of events led to preservation of the nesting trace and eggs. First, the female theropod excavated the nest depression within an existing soil complex developed in overbank muds. Within minutes of laying the eggs in the depression she covered the clutch with excavated sediment and possibly some vegetation. At some point thereafter the clutch failed for reasons unknown. Subsequent decomposition of organic matter (plants and eggs) resulted in reducing conditions within the nest. Finally, pedogenesis and bioturbation produced the homogeneous structure of the mudstone, destroying all primary depositional fabric.

It should be noted that the Flaming Cliffs nesting trace is similar to a nest previously reported from the Willow Creek anticline that contained the remains of 11 disarticulated juvenile hadrosaurs (Horner and Makela 1979). The 2-m-long by 0.75 -m-deep concave structure containing the juveniles occurred in fine-grained brown mudstone, whereas fine-grained green mudstone filled the depression. This suggests that, at least in some circumstances, sediment color differences, along with differential compaction, cementation, and weathering, may provide the initial evidence for recognizing nesting traces in the field.

\section{Water Vapor Conductance Rate}

Calculation of water vapor conductance rates for the Continuoolithus eggs also supports interpretations of substrate burial based on sedimentologic evidence of the nesting trace. In contrast to the excellent preservation of MOR 301A, all other Continuoolithus eggs from Egg Mountain show marked compaction (Hirsch and Quinn 1990). Therefore, whether MOR 301A provides a representative model for $C$. canadensis egg morphology remains uncertain. Applying the standard equations of Hoyt (1979) and Paganelli et al. (1974) for determining volume differs only slightly $(0.6 \%)$ from the geometric model (Table 4$)$. However, determining surface area using their equations produces results differing by about $9 \%$ from our geometric model of MOR 301A. Overall conductance of the $C$. canadensis egg would therefore be $3.6 \times$ greater than that of an avian egg of equivalent mass, rather than $3.9 \times$ calculated by the geometric method. Consequently, when considering our gas conductance values, one should assume an approximate $10 \%$ margin of error. Nevertheless, a $3.9 \times$ greater conductance rate supports incubation within sediment, either with or without additional vegetation, rather than subaerial exposure of eggs and attendance by an adult, as is characteristic of most birds. In addition, this value is almost twice that of megapodes, the only birds that fully bury their eggs in vegetation (Seymour and Ackerman 1980; Booth and Seymour 1987).

Substantial variations in pore density and conductance rates occur among the six eggs (Table 3); however, due to a small sample size, the significance of these variations cannot be statistically tested. On average, the equator displays the highest porosity and conductance, whereas the tapering pole exhibits the lowest values. The maximum conductance of some eggs occurs at the tapering pole, whereas in other eggs it lies at the equator or blunt pole. Sampling bias likely accounts for the majority of this variation, as some of the most extreme zonal values are associated with a small sampled area. Overall, the Continuoolithus eggs show the highest conductance in the equatorial zone, moderate value in the blunt pole, and a much lower value in the tapering pole. This variation appears to match the variation in overall volume for each of these zones, with the highest conductance corresponding to the largest volume and the lowest values with the much smaller volume of the tapering pole. A similar correlation of zonal conductance to zonal volume also occurs in Troodon eggs (Varricchio et al. 2013).

\section{CONCLUSIONS}

Sedimentologic evidence suggests that at the Flaming Cliffs locality a theropod excavated a $35-\mathrm{cm}-$ long, $7-\mathrm{cm}$-wide nest on an alluvial floodplain in a well-drained, fine-grained overbank deposit. Following oviposition of at least four eggs, the adult backfilled the nest with a thin layer of plant material and sediment from the excavation. Failure of the egg clutch contributed to reducing conditions within the nest; however, relatively high $\mathrm{pH}$ and low to negative Eh led to the unusual preservation of both plant remains and the calcium carbonate eggshell. Alternatively, these redox conditions may have developed after transition of the soil complex to the freshwater phreatic zone during early diagenesis.

Eggs from the Flaming Cliffs locality and elsewhere in the Two Medicine Formation (Hirsch and Quinn 1990) are referable to Continuoolithus canadensis, an oospecies that was originally described from the temporally and stratigraphically equivalent Oldman Formation of southern Alberta. Geometric modeling yields an egg volume and surface area of approximately $193.5 \mathrm{~cm}^{3}$ and $180.4 \mathrm{~cm}^{2}$, respectively. This method provides a more accurate estimate than equations developed for avian eggs because of the more elongate shape of these theropod eggs. Calculations of $\mathrm{G}_{\mathrm{H} 2 \mathrm{O}}$ for different zones also emphasize the asymmetric shape of the egg. Continuoolithus eggs show the highest conductance $(46 \%)$ in the equatorial zone, moderate value $(37 \%)$ in the blunt pole, and a significantly lower value $(17 \%)$ in the tapering pole. This variation appears to correspond to the variation in overall volume represented by each of these zones. We estimate the overall water vapor conductance rate as $3.9 \times$ greater than an avian egg of similar mass. This relatively high 
conductance rate (compared with most avian eggs) further supports the sedimentologic evidence from the nesting trace that indicates that $C$. canadensis eggs were incubated in a substrate rather than subaerially exposed and attended by an adult. The egg porosity and substrate burial is consistent with that hypothesized for the vast majority of dinosaurs and differs from troodontids, which share a closer evolutionary relationship to birds.

\section{ACKNOWLEDGMENTS}

We thank Jack Horner, Curator of Paleontology at the Museum of the Rockies, for access to the Beatrice Taylor Field Research Station, the Gabriel Laboratory for Molecular and Cellular Biology, and for permission to sample these specimens. We thank the 1994 and 1995 participants in the Museum of the Rockies Paleontology Field School who assisted in the discovery and collection of MOR 3062. We also thank M. and T. Kohler for continued support of fieldwork at Egg Mountain and the Willow Creek anticline. We acknowledge and appreciate the advice, editing, and discussion of gas conductance by R. Jackson. This research was supported by National Science Foundation grant \#0847777 (EAR) to D. Varricchio.

\section{REFERENCES}

Ar, A., AND RAHN, H., 1985, Pores in avian eggshells: gas conductance, gas exchange and embryonic growth rate: Respiration Physiology, v. 61, p. 1-20.

Ar, A., Paganelli, C.V., Reeves, R.B., Greene, D.G., and Rahn, H., 1974, The avian egg: water vapour conductance, shell thickness, and functional pore area: Condor, v. 76, p. 153-158.

Balkan, M., Karakas, R., and Biricik, M., 2006, Changes in eggshell thickness, shell conductance and pore density during incubation in the Peking Duck (Anas platyrhynchos f. dom.): Ornis Fennica, v. 83, p. 117-123.

BARTA, D., 2014, A phylogenetic approach to understanding dinosaur egg diversity and the evolution of reproductive traits within Dinosauria: Unpublished M.S. thesis, Montana State University, Bozeman, 154 p.

Birchard, G., and Kilgore, D., 1980, Conductance of water vapor in eggs of burrowing and non-burrowing birds: implications for embryonic gas exchange: Physiological Zoology, v. 53, p. 284-292.

Board, R., AND ScotT, V., 1980, Porosity of the avian eggshell: American Zoologist, v. 20 , p. $339-349$.

Bоотн, D., 1989, Regional changes in shell thickness, shell conductance, and pore structure during incubation in eggs of the Mute Swan: Physiological Zoology, v. 62, p. 607-620.

Booth, D., and Seymour, R., 1987, Effect of eggshell thinning on water vapor conductance of Mallee fowl eggs: Condor, v. 89, p. 453-459.

Brady, N.C., AND WeIL, R.R., 2002, The Nature and Properties of Soils: Upper Saddle River, New Jersey, Prentice Hall, 960 p.

Chiappe, L., Schmitt, J., Jackson, F., Garrido, A., Dingus, L., and Grellet-Tinner, G., 2004, Nest structure for sauropods: sedimentary criteria for recognition of dinosaur nesting traces: PALAIOS, v. 19, p. 89-95.

Deeming, D., 2002, Avian Incubation: Behavior, Environment, and Evolution: Oxford, UK, Oxford University Press, 421 p.

Deeming, D., 2004, Reptilian Incubation: Environment, Evolution and Behavior: Nottingham, UK, Nottingham University Press, 349 p.

DeEming, D., 2006, Ultrastructural and functional morphology of eggshells supports the idea that dinosaur eggs were incubated buried in a substrate: Palaeontology, v. 49, p. 171-185.

Deeming, D., and Thompson, M., 1991, Gas exchange across reptilian eggshells, in Deeming, C., and Ferguson, M., eds., Egg Incubation: Its Effects on Embryonic Development in Birds and Reptiles: Cambridge, UK, Cambridge University Press, p. $277-284$.

Donaire, M., and López-Martínez, N., 2009, Porosity of late Paleocene Ornitholithus eggshells (Tremp Formation, south-central Pyrenees, Spain): palaeoclimatic implications: Palaeogeography, Palaeoclimatology, Palaeoecology, v. 279, p. 147-159.

EвERTH, D.A., 1990, Stratigraphy and sedimentology of vertebrate microfossil sites in the uppermost Judith River Formation (Campanian). Dinosaur Provincial Park, Alberta, Canada: Palaeogeography, Palaeoclimatology, Palaeoecology, v. 78, p. 1-36.

Eberth, D.A., Thomas, R.G., and Deino, A., 1992, Preliminary K- Ar dates from bentonites in the Judith River and Bearpaw formations (Upper Cretaceous) of Dinosaur Provincial Park, southern Alberta, Canada, in Mateer, N.J., and Chen, P.J., eds., Aspects of Nonmarine Cretaceous Geology: Beijing, China Ocean Press, p. 296304.

ElzANowski, A, 1981, Embryonic bird skeletons from the Late Cretaceous of Mongolia: Palaeontologica Polonica, v. 42, p. 147-179.

Fernández, M.S., Garcia, R.A., Fiorelli, L., Scolaro, A., Salvador, R.B., Cotaro, C.N., Kaiser, G.W., And Dyke, G.J., 2013, A large accumulation of avian eggs from the Late Cretaceous of Patagonia (Argentina) reveals a novel nesting strategy in Mesozoic birds: PLoS ONE, v. 8, no. 4, e61030, doi: 10.1371/journal.pone.0061030.
Freytet, P., And Verrecchia, E.P., 2002, Lacustrine and palustrine carbonate petrography: an overview: Journal of Paleolimnology, v. 27, p. 221-237.

Gill, J., AND CobBan, W., 1973, Stratigraphy and geologic history of the Montana Group and equivalent rocks, Montana, Wyoming and North and South Dakota: United States Geological Survey, Professional Paper, no. 776, p. 1-37.

Goodwin, M.B., and Deino, A.L., 1989, The first radiometric ages from the Judith River Formation (Upper Cretaceous), Hill County, Montana: Canadian Journal of Earth Sciences, v. 26, p. 1384-1391.

Goudie, A.S., 1983, Calcrete, in Goudie, A.S., and Pye, K., eds., Chemical Sediments and Geomorphology: London, Academic Press, p. 93-131.

Grellet-Tinner, G., AND ChiaPPE, L.M., 2004, Dinosaur eggs and nesting: implications for understanding the origin of birds, in Currie, P.J., Koppelhus, E.B., Shugar, M.A., and Wright, J.L., eds., Feathered Dragons: Studies on the Transition from Dinosaurs to Birds: Bloomington, Indiana University Press, p. 185-214.

Grellet-Tinner, G., Chiappe, L., Norell, M., And BottJer, D., 2006, Dinosaur eggs and nesting behaviors: a paleobiological investigation: Palaeogeography, Palaeoclimatology, Palaeoecology, v. 232, p. 294-321.

Grellet-Tinner, G., Fiorelli, L.E., and Salvador, R.B., 2012, Water vapor conductance of the Lower Cretaceous dinosaurian eggs from Sanagasta, La Rioja, Argentina: paleobiological and paleoecological implications for South American faveoloolithid and megaloolithid eggs: PALAIOS, v. 27, no. 1, p. 35-47.

Grigorescu, D., Weishampel, D., Norman, D., Seclamen, M., Rusu, M., Baltres, A., And Teodorescu, V., 1994, Late Maastrichtian dinosaur eggs from the Hateg Basin (Romania), in Carpenter, C., Hirsh, K.F., and Horner, J.R., eds., Dinosaur Eggs and Babies: Cambridge, UK, Cambridge University Press, p. 75-87.

GrigG, G., AND Beard, L., 1985, Water loss and gain by eggs of Crocodylus porosus, related to incubation age and fertility, in Grigg, B., Shine, R., and Ehmann H., eds., Biology of Australasian Frogs and Reptiles: Sydney, Surry Beatty, p. 353-359.

Hirsch, K., AND QuinN, B., 1990, Eggs and eggshell fragments from the Upper Cretaceous Two Medicine Formation of Montana: Journal of Vertebrate Paleontology, v. 10, p. 491-511.

HoRNER, J., 1987, Ecological and behavioral implications derived from a dinosaur nesting site, in Czerkas, S., and Olson, E., eds., Dinosaurs Past and Present Volume II: Seattle, University of Washington Press, p. 51-63.

HorNER, J., 1997, Rare preservation of an incompletely ossified fossil embryo: Journal of Vertebrate Paleontology, v. 17, p. 431-434.

Horner, J., AND Makela, R., 1979, Nest of juveniles provides evidence of family structure among dinosaurs: Nature, v. 282, p. 296-298.

Hoyt, D., 1979, The effect of shape on the surface-volume relationships of bird: Condor, v. 78, p. 343-349.

Jackson, F., Varricchio, D., JaCkson, R., Vila, B., AND Chiappe, L., 2008, Comparison of water vapor conductance in a titanosaur egg from the Upper Cretaceous of Argentina and a Megaloolithus siruguei egg from Spain: Palaeobiology, v. 34, p. 229 246.

Jin, X., Azuma, Y., Jackson, F.D., And Varricchio, D.J., 2007, Giant dinosaur eggs from the Tiantai basin, Zhejiang Province, China: Canadian Journal of Earth Science, v. 44 , p. $81-88$.

Jin, X., Jackson, F., Varriccho, D.J., Azuma, Y., and He, T., 2010, The first Dictyoolithus egg clutches from the Lishui basin, Zhejiang Province, China: Journal of Vertebrate Paleontology, v. 30, no. 1, p. 188-195.

Kolesnikov, C.H., And Sochava, A.V., 1972, A paleobiological study of Cretaceous dinosaur eggshell from the Gobi: Paleontological Journal, v. 6, p. 235-245.

Kurochion, E.N., Chatterjee, S., and Mikhailov, K.E., 2013, An embryonic enantiornithine bird and associated eggs from the Cretaceous of Mongolia: Paleontological Journal, v. 47, no. 11, p. 1252-1269.

Lageson, D., Schmitt, J., Horton, H., Kalakay, T., and Burton, B., 2001, Influence of Late Cretaceous magmatism on the Sevier orogenic wedge, western Montana: Geology, v. 29, p. 723-726.

Lorenz, J., 1981, Sedimentary and tectonic history of the Two Medicine Formation, Late Cretaceous (Campanian), northwestern Montana: Unpublished Ph.D. thesis, Princeton University, Princeton, New Jersey, $225 \mathrm{p}$.

Lorenz, J., And Gavin, W., 1984, The geology of the Two Medicine Formation and the sedimentology of a dinosaur nesting ground, in McBane, J.D., and Garrison, P.B., eds., Northwestern Montana and Adjacent Canada: Montana Geological Society 1984 Field Conference and Symposium, p. 175-186.

Miall, A.D., 1996, The Geology of Fluvial Deposits: Sedimentary Facies, Basin Analysis, and Petroleum Geology: New York, Springer, 598 p.

Mikhailov, K., 1997, Fossil and recent eggshell in amniotic vertebrates: fine structure, comparative morphology and classification: Special Papers in Palaeontology, v. 56, p. $1-80$.

Mikhailov, K., Bray, E., AND Hirsch, K., 1996, Parataxonomy of fossil egg remains (Veterovata): principles and applications: Journal of Vertebrate Paleontology, v. 16, p. 763-769.

Moody, J.A., Pizzuto, J.E., and Meade, R.H., 1999, Ontogeny of a floodplain: Geological Society of America Bulletin, v. 111, p. 291-303.

Mudge, M., 1970, Origin of the disturbed belt in northwestern Montana: Geological Society of America Bulletin, v. 81, p. 377-392.

Paganelli, C.V., Olszowka, A., And Ar, A., 1974, The avian egg: surface area, volume and density: Condor, v. 76, p. 319-325.

Retallack, G., 1990, Soils of the Past: Boston, Unwin Hyman, 520 p.

Retallack, G., 1997, Dinosaurs and dirt: Dinofest International Proceedings, 345-359 p. 
Roberts, E., And Hendrix, M., 2000, Taphonomy of a petrified forest in the Two Medicine Formation (Campanian), northwest Montana: implications for palinspastic restoration of the Boulder Batholith and Elkhorn Mountain Volcanics: PALAIOS, V. 15 , p. $476-482$

Rogers, R., 1998, Sequence analysis of the Upper Cretaceous Two Medicine and Judith River formations, Montana: nonmarine response to the Claggett and Bearpaw marine cycles: Journal of Sedimentary Research, v. 68, p. 615-631.

Rogers, R.R., AND Swisher, C.C., 1996, The Clagget and Bearpaw transgression revisited: new data and a review of possible drivers: Geological Society of America Abstracts with Programs, v. 28, p. 62.

Rogers, R.R., Swisher, C.C., AND Horner, J., 1993, 40Ar/39Ar Age and correlation of the non-marine Two Medicine Formation (Upper Cretaceous), northwestern Montana: Canadian Journal of Earth Sciences, v. 30, p. 1066-1075.

Rokitka, M., AND RaHN, H., 1987, Regional differences in shell conductance and pore density of avian eggs: Respiration Physiology, v. 68, p. 371-376.

SABATH, K., 1991, Upper Cretaceous amniotic eggs from the Gobi Desert: Acta Palaeontologica Polonica, v. 36, p. 151-192.

Sahni, A., Tandon, S.K., Jolly, A., Bajpai, S., Sood, A., and Srinivasan, S., 1994, Upper Cretaceous dinosaur eggs and nesting sites from the Deccan volcano: sedimentary province of peninsular India), in Carpenter, C., Hirsh, K.F., and Horner, J.R., eds., Dinosaur Eggs and Babies: Cambridge, UK, Cambridge University Press, p. 204-226.

SAlvador, R.B., AND Fiorelli, L.E., 2011, Water vapor conductance in fossil early bird eggs and non-avian theropods: implications for the evolution of modern birds exposed nest structure: XXII Congresso Brasileiro de Paleontologia. Paleontologia: Caminhando pelo Tempo, 23-28 October 2011, p. 742-744.

SCHAFF, R.J., 2012, Incubation of Continoolithus canadensis eggs from the Late Cretaceous Two Medicine Formation of Montana: Unpublished M.S. thesis, Montana State University, Bozeman, $91 \mathrm{p}$.

Schweitzer, M., Jackson, F.D., Chiappe, L., Schmitt, J.G., Calvo, J, and Rubilar, J.D., 2002, Avian eggs and embryos from the Late Cretaceous of Patagonia Argentina: Journal of Vertebrate Paleontology, v. 22, no. 1, p. 191-195.

SEYmour, R., 1979, Dinosaur eggs: gas conductance through the shell, water loss during incubation and clutch size: Paleobiology, v. 5, p. 1-11.

Seymour, R., And Ackerman, R., 1980, Adaptions to underground nesting in birds and reptiles: Integrative and Comparative Biology, v. 20, p. 437-447.

Seymour, R., Vleck, D., And Vleck, C., 1986, Gas exchange in the incubation mounds of megapode birds: Journal of Comparative Physiology, v. 156, p. 773-782.
Seymour, R., Vleck, D., Vleck, C., And Booth, D., 1987, Water relations of buried eggs of mound building birds: Journal of Comparative Physiology, v. 157, p. 413-422.

Shelton, J.A., 2007, Application of sequence stratigraphy to the nonmarine Upper Cretaceous Two Medicine Formation, Willow Creek Anticline, Northwestern, Montana: Unpublished M.S. thesis, Montana State University, Bozeman, 238 p.

Shott, A.R., And Preston, F.W., 1975, The surface area of an egg: Condor, v. 77, no. 1, p.103-104.

VARricChIO, D.J., AND JACKSON, F.D., 2004, A phylogenetic assessment of prismatic dinosaur eggs from the Cretaceous Two Medicine Formation of Montana: Journal of Vertebrate Paleontology, v. 24, p. 931-937.

Varricchio, D., Jackson, F., Borkowski, J., And Horner, J., 1997, Nest and egg clutches of the dinosaur Troodon formosus and the evolution of avian reproductive traits: Nature, v. 385 , p. $247-250$.

VARRICCHIO, D., JACKSON, F., AND TRUeman, C., 1999, A nesting trace with eggs for the Cretaceous theropod dinosaur Troodon formosus: Journal of Vertebrate Paleontology, v. 19 , p. $91-100$.

Varricchio, D.J., Koeberl, C., Raven, R.F., Wolbach, W., Elsik, W.C., and Miggins, D.P., 2010, Tracing the Manson Impact event across the Western Interior Cretaceous Seaway, in Reimold, W.U., and Gibson, R.L., eds., Proceedings of the Conference on Large Meteorite Impacts and Planetary Evolution: Geological Society of America, Special Paper 465.

VARRICCHIO, D.J., JACKSON, F.D., JACKSON, R.A., AND ZelenitsKy, D.K., 2013, Porosity and water vapor conductance of two Troodon formosus eggs: an assessment of incubation strategy in a maniraptoran dinosaur: Paleobiology, v. 39, p. 278-296.

Williams, D. Seymour, R. and Kerourio, P. 1984, Structure of fossil dinosaur eggshell from the Aix Basin, France: Palaeogeography, Palaeoclimatology, Palaeoecology, v. 45, p. 23-37.

Wright, V.P., AND TuCKER, M.E., 1991, Calcretes: an introduction, in Wright, V.P., and Tucker, M.E., eds., Calcretes: International Association of Sedimentologists Reprint Series Vol. 2, Oxford, UK, Wiley-Blackwell, p. 1-22.

Zelenitsky, D., Hills, L., And Currie, P., 1996, Parataxanomic classification of ornithoid eggshell fragments from the Oldman Formation (Judith River Group; Upper Cretaceous), southern Alberta: Canadian Journal of Earth Sciences, v. 33, p. $1655-1667$.

Zelenitsky, D., Modesto, S., and Currie, P., 2002, Bird-like characteristics of troodontid theropod eggshell: Cretaceous Research, v. 23, p. 297-305.

Received 31 May 2014; accepted 10 February 2015 